\title{
ANALISIS BUKU MATEMATIKA SMA BERDASARKAN STANDARD FOR MATHEMATICAL PRACTICE
}

\author{
${ }^{1}$ Jeri Araiku, ${ }^{2}$ Somakim, ${ }^{3}$ Weni Dwi Pratiwi, ${ }^{4}$ Nadia Faradilla, ${ }^{5}$ Annisa Oktavia Lestari \\ Universitas Sriwijaya, Jalan Raya Palembang-Prabumulih KM 32, Indralaya, Ogan Ilir, Sumatra Selatan, 30662, \\ Telp/Fax: (0711) 580058, Indonesia \\ e-mail: jeriaraiku@fkip.unsri.ac.id
}

\begin{abstract}
Abstrak
Tujuan penelitian ini adalah untuk menganalisis buku penilaian matematika wajib SMA karya Prof. Wono Setya Budhi, Ph.D. berdasarkan Standard for Mathematical Practice (SMP) pada indikator menggunakan alat-alat dan strategi yang tepat (MP5), ketepatan (MP6), mencari dan menggunakan pola (MP7), dan mencari dan menyatakan keteraturan dalam penalaran berulang (MP8). Metode yang digunakan adalah analisis konten, yang terdiri atas desk evaluation, reduksi data dan deskripsi data hasil analisis. Berdasarkan hasil analisis, diperoleh kesesuaian buku dengan indikator MP5 sebesar 36,84\%, MP6 dan MP8 sebesar 100\%, serta MP7 sebesar 47,37\%. Kesesuaian indikator ini menunjukan bahwa buku yang dianalisis dapat membantu siswa untuk mengambangkan kemampuan berpikir tingkat tinggi, motivasi belajar, serta keterampilan menggunakan alat-alat dan aplikasi-aplikasi matematika. Selain kesesuaian buku dengan SMP, kelebihan lain buku ini adalah terdapat video tutorial di setiap bab yang dapat diakses dengan memindai barcode. Oleh sebab itu, buku ini sangat disarankan untuk digunakan oleh siswa agar dapat belajar secara mandiri terutama pada masa pandemi COVID-19 saat ini.
\end{abstract}

Kata Kunci: Analisis buku matematika, Standard for mathematical practice, Video tutorial, Matematika SMA

\begin{abstract}
The aim of this study was to analyze the compulsory high school mathematics assessment books by Prof. Wono Setya Budhi, Ph.D. based on the Standard for Mathematical Practice (SMP) on indicators use appropriate tools strategically (MP5), attend to precision (MP 6), look for and make sense of structure (MP 7), and look for and make use of repeated reasoning (MP 8). The method used is content analysis, consisted of desk evaluation, data reduction and describing the data from the analysis. Based on the analysis results, the suitability of the book with the MP5 indicator is $36.84 \%$, MP6 and MP8 is $100 \%$, and MP7 is $47.37 \%$. The suitability of these indicators show that books can help students to develop higher-order thinking skills, learning motivation, and skills using mathematical tools and applications. In addition to the suitability of books with SMP, another merit of this book is that there are video tutorials in each chapter that can be accessed by scanning barcodes. Therefore, this book is highly recommended for students to use to learn independently, especially during the current COVID-19 pandemic.
\end{abstract}

Keywords: Mathematics book analysis, Standard for mathematical practice, Tutorial video, Highschool mathematics

\section{PENDAHULUAN}

Penyusunan kurikulum dan pemilihan konten pendidikan matematika tetap menjadi masalah yang menantang dan kontemporer (Čeretková, Šedivý, Molnár, \& Petr, 2008; Chang \& Silalahi, 2017). Konten pendidikan yang dijabarkan dengan baik, metode dalam pengajaran matematika dan organisasi pendidikan yang koheren membentuk suatu proses di mana seorang siswa memperoleh pengetahuan, minat, dan keterampilan siswa (Schmidt, McKnight, Valverde, Houang, \& Wiley, 1997; Robitaille \& Travers, 1992; Okeeffe, 2013). Konten pendidikan ini biasanya dijabarkan dalam bentuk buku teks matematika (Gene, Zacharos, Lavidas, \& Koustourakis, 2018). Buku teks matematika sangat mempengaruhi apa yang 
diajarkan di ruang kelas karena guru-guru menggunakan buku teks sebagai panduan harian untuk mengatur proses pembelajaran mereka, baik sehubungan dengan konten pengajaran dan metode pengajaran (Valverde, Bianchi, Wolfe, Schmidt, \& Houang, 2002; Van den HeuvelPanhuizen \& Wijers, 2005).

Matematika merupakan salah satu mata pelajaran utama di setiap jenjang pendidikan dan buku teks matematika memegang peranan penting dalam proses pembelajarannya. Buku teks membantu menjelaskan konsep abstrak matematika menjadi bentuk informal yang lebih mudah dipahami siswa (Valverde, Bianchi, Wolfe, Schmidt, \& Houang, 2002). Buku teks matematika juga membantu dalam menjelaskan hirarki dan keterkaitan antar materi, merangsang minat belajar, menambah kosa kata termasuk istilah teknis, meningkatkan kemampuan berpikir melalui latihan dan pemecahan masalah, memiliki fitur tambahan tertentu untuk mendukung pembelajaran (Basturkmen, 2010; Graves, 2000; Čeretková, Šedivý, Molnár, \& Petr, 2008).

Selama beberapa dekade terakhir, banyak penelitian yang berpusat pada analisis buku pelajaran sekolah dari berbagai sudut pandang. Beberapa di antaranya merupakan studi perbandingan konten beberapa buku (Li, 2000; Mayer, Sims, \& Hidet, 1995; Taqiyuddin, 2019), peran buku teks dalam pengajaran dan pembelajaran matematika (Čeretková, Šedivý, Molnár, \& Petr, 2008), hubungan antara matematika standar kurikulum/silabus dan buku pelajaran (Chang \& Silalahi, 2017), dan evaluasi buku teks matematika (Arroida \& Retnawati, 2018; Schmidt, McKnight, Valverde, Houang, \& Wiley, 1997). Penelitian-penelitian ini berfokus pada standar konten. Namun, tidak kalah penting untuk menganalisis buku matematika berdasarkan dengan standar pelaksanaan/prosesnya, karena fokus pada standar konten dalam pembelajaran juga harus sejalan standar proses (O'Connell \& SanGiovanni, 2013). Terlebih lagi, dalam pembelajaran matematika, konten akan selalu berubah berdasarkan jenjang pendidikan, namun standar dalam pelaksanaannya tidak (CCSSI, 2020; O'Connell \& SanGiovanni, 2013; NCTM, 2000; Clayton, 2014). Standar pelaksanaan ini disebut sebagai Standard for Mathematical Practice (SMP).

Terdapat 8 SMP yang dirumuskan untuk membantu siswa mengembangkan kemampuan berpikir matematis (CCSSI, 2020), yaitu: (1) Memaknai masalah dan menyelesaikannya (MP1); (2) Menalar secara abstrak dan kuantitatif (MP2); (3) Membangun argumen dan mengkritisi argumen orang lain (MP3); (4) Memodelkan dengan matematika (MP4); (5) Menggunakan alat-alat dan strategi yang tepat (MP5); (6) Ketepatan (MP6); (7) Mencari dan menggunakan pola (MP7), dan; (8) Mencari dan menyatakan keteraturan dalam penalaran berulang (MP8). Fokus terhadap SMP di ruang kelas dapat membantu siswa dalam meningkatkan higher order thinking skills (HOTS), motivasi belajar, bahkan penggunaan 
teknologi pembelajaran (Apino \& Retnawati, 2016; Courtney, 2014; Eyyam \& Yaratan, 2014; Mateas, 2016; Tajudin, 2017).

Salah satu buku yang memenuhi beberapa kriteria SMP adalah buku penilaian (BUPENA) matematika SMA wajib karya Prof. Wono Setya Budhi, Ph.D (Araiku, Somakim, Pratiwi, Lestari, \& Faradilla, 2020). Berdasarkan analisis yang dilakukan pada buku kelas X, XI, dan XII, diketahui bahwa buku-buku ini memenuhi kriteria MP1, MP2, MP3 sebesar 100\% dan MP4 sebesar 94,74\%. Buku-buku tersebut memiliki masalah dengan tingkat kesulitan yang beragam, sehingga sangat disarankan untuk digunakan di kelas agar dapat mendorong siswa untuk meningkatkan kemampuan berpikir tingkat tingginya (HOTS) (Araiku, Somakim, Pratiwi, Lestari, \& Faradilla, 2020). Selain itu, dengan adanya konteks yang beragam, buku teks matematika ini juga dapat meningkatkan motivasi belajar siswa serta memberikan makna dalam belajar matematika terutama dalam penyelesaian masalah dalam kehidupan sehari-hari (Magfirah, Maidiyah, \& Suryawati, 2019; Widjaja, 2013).

Berdasarkan pentingnya untuk menganalisis buku teks matematika, tidak hanya berdasarkan konten melainkan juga berdasarkan standar prosesnya, serta analisis pada penelitian terdahulu yang baru menjelaskan 4 dari 8 SMP, maka penelitian terhadap buku penilaian matematika wajib SMA kelas X, XI, dan XII ini bertujuan untuk (1) menganalisis kesesuaian berdasarkan SMP untuk indikator MP5, MP6, MP7, dan MP8, serta (2) menganalisis kelebihan lain di luar SMP.

\section{METODE PENELITIAN}

Penelitian ini merupakan penelitian deskriptif kualitatif. Metode yang digunakan dalam penelitian ini adalah analisis konten (Borg, Gall, \& Gall, 2003; Farzan, 2009), di mana akan dilakukan desk evaluation oleh tim penelitian untuk melihat kesesuaian buku berdasarkan Standard for Mathematical Practice (SMP). Objektifitas pemilihan SMP sebagai indikator analisis didasarkan pada tiga alasan. Pertama, fokus pada standar konten dalam pembelajaran matematika harus sejalan standar prosesnya. Kedua, konten matematika selalu berubah berdasarkan jenjang pendidikan, namun standar prosesnya tetap. Ketiga, belum banyak penelitian serupa yang berfokus pada standar proses, sehingga perlu untuk dilakukan penelitian. Data hasil analisis akan direduksi dan dideskripsikan dengan dukungan teori serta hasil penelitian yang relevan.

Sampel penelitian adalah buku penilaian (BUPENA) matematika wajib SMA kelas X, XI, dan XII Prof. Wono Setya Budhi, Ph.D. Seluruh edisi BUPENA SMA dipilih sebagai objek 
penelitian karena penting untuk melihat konsistensi fitur yang terdapat pada setiap buku sehingga dapat memberikan kesimpulan yang lebih komprehensif.

Untuk menilai kesesuaian buku, maka indikator SMP yang akan digunakan dapat dilihat pada Tabel 1 berikut.

Tabel 1. Indikator Standards for Mathematical Practices

\begin{tabular}{|c|c|c|c|}
\hline SMP & Siswa mampu untuk & Sikap guru & Indikator buku \\
\hline MP5 & $\begin{array}{l}\text { - mempertimbangkan ketersediaan } \\
\text { alat-alat ketika menyelesaikan } \\
\text { masalah } \\
\text { - membuat keputusan mengenai } \\
\text { pemilihan alat } \\
\text { - mendekteksi kemungkinan kesalahan } \\
\text { ketika menggunakan alat-alat secara } \\
\text { strategis menggunakan estimasi dan } \\
\text { pengetahuan matematika lain } \\
\text { - dapat menggunakan teknologi }\end{array}$ & $\begin{array}{l}\text { - Menyediakan berbagai alat selama } \\
\text { pembelajaran matematika } \\
\text { - Mengajar dan memodelkan } \\
\text { penggunaan alat yang sesuai } \\
\text { - Memfasilitasi diskusi terkait } \\
\text { penggunaan alat } \\
\text { - Memodelkan penggunaan teknologi } \\
\text { untuk mengeksplorasi dan } \\
\text { memperdalam pemahaman siswa }\end{array}$ & $\begin{array}{l}\text { Terdapat fitur yang } \\
\text { menjelaskan alat } \\
\text { atau media yang } \\
\text { dapat membantu } \\
\text { menyelesaikan } \\
\text { masalah matematis. }\end{array}$ \\
\hline MP6 & $\begin{array}{l}\text { - Menggunakan defisini dan kosa kata } \\
\text { matematis yang jelas untuk } \\
\text { mengomunikasikan nalar } \\
\text { - Menspesifikasi label, satuan, } \\
\text { jawaban di dalam konteks masalah } \\
\text { - Memahami dan menjelaskan } \\
\text { pengertian symbol matematis }\end{array}$ & $\begin{array}{l}\text { - Menyediakan konteks dan mading } \\
\text { akademik } \\
\text { - Menggeneralisasi bagan jangkar } \\
\text { dengan contoh-contoh yang relevan } \\
\text { - Memodelkan dan mengharapkan } \\
\text { penggunaan bahasa dan kosa kata } \\
\text { matematis dalam keseharian } \\
\text { - Memodelkan label, satuan dan } \\
\text { jawaban spesifik dalam konteks } \\
\text { masalah } \\
\text { - Menyediakan kesempatan pada } \\
\text { siswa untuk mengeksplorasi symbol } \\
\text { dan pengertian matematisnya }\end{array}$ & $\begin{array}{l}\text { Masalah matematis } \\
\text { yang menekankan } \\
\text { pada penggunaan } \\
\text { symbol, satuan, dan } \\
\text { konteks masalah. }\end{array}$ \\
\hline MP7 & $\begin{array}{l}\text { - Memerhatikan secara seksama untuk } \\
\text { menentukan pola dan struktur (sifat) } \\
\text { yang mungkin di dalam sebuah } \\
\text { masalah } \\
\text { - Menganalisis pola dan } \\
\text { mengaplikasikannya dalam konteks } \\
\text { matematis yang sesuai } \\
\text { - Menggunakan pengetahuan awal dari } \\
\text { bilangan dan hubungannya untuk } \\
\text { menalar dan menyelesaikan masalah } \\
\text { matematis }\end{array}$ & $\begin{array}{l}\text { - Memilih masalah yang menantang } \\
\text { dan terkait dengan menggunakan } \\
\text { pola } \\
\text { - Membangun kepekaan bilangan } \\
\text { sehari-hari } \\
\text { - Memfasilitasi proses menggunakan } \\
\text { pola dan struktur untuk menghitung } \\
\text { dan menyelesaikan masalah }\end{array}$ & $\begin{array}{l}\text { Terdapat masalah } \\
\text { matematis yang } \\
\text { dapat diselesaikan } \\
\text { dengan strategi } \\
\text { mencari pola }\end{array}$ \\
\hline MP8 & $\begin{array}{l}\text { - Menyadari pengulangan perhitungan } \\
\text { dan mencari metode/representasi } \\
\text { yang lebih efisien untuk } \\
\text { menyelesaikan suatu masalah } \\
\text { - Mengevaluasi kelayakan hasilnya } \\
\text { selama proses penyelesaian masalah }\end{array}$ & $\begin{array}{l}\text { - Menyampaikan proses penyelesaian } \\
\text { masalah oleh guru maupun siswa } \\
\text { - Menyediakan waktu dan } \\
\text { kesempatan untuk menemukan } \\
\text { metode yang efisien untuk suatu } \\
\text { penyelesaian masalah }\end{array}$ & $\begin{array}{l}\text { Masalah matematis } \\
\text { menekankan pada } \\
\text { solusi yang efisien } \\
\text { dengan } \\
\text { membandingkan } \\
\text { beberapa metode } \\
\text { penyelesaian }\end{array}$ \\
\hline
\end{tabular}

Kesesuaian buku dengan indikator SMP dihitung berdasarkan persentase kemunculan indikator di setiap bab. Perhitungan persentase kesesuaian dapat dilihat pada rumus (1) berikut. 
Persentase kesesuaian $=\frac{\text { banyaknya bab yang memunculkan indikator } S M P}{\text { jumlah bab }} \times 100 \%$

Kategori kesesuaian buku dengan indikator dapat dilihat pada Tabel 2.

Tabel 2. Kategori kesesuaian indikator

\begin{tabular}{cl}
\hline Persentase & \multicolumn{1}{c}{ Kesesuaian } \\
\hline $75 \%<p \leq 100 \%$ & Sangat sesuai \\
$50 \%<p \leq 75 \%$ & Sesuai \\
$25 \%<p \leq 50 \%$ & Cukup sesuai \\
$0 \% \leq p \leq 25 \%$ & Kurang sesuai \\
\hline
\end{tabular}

\section{HASIL DAN PEMBAHASAN}

Hasil

Buku penilaian matematika wajib SMA terdiri atas 19 bab, dengan sebaran 7 bab di kelas X, 8 bab di kelas XI, dan 4 bab di kelas XII. Setiap bab di buku ini dianalisis untuk melihat kemunculan indikator MP5, MP6, MP7, dan MP8 secara eksplisit. Berdasarkan desk evaluation terhadap kesesuaian isi buku dengan $S M P$, maka diperoleh hasil sebagai berikut.

Tabel 2. Persentase kesesuaian buku

\begin{tabular}{lcc}
\hline SMP & Persentase & Kesesuaian \\
\hline MP5 & $36,84 \%$ & Cukup sesuai \\
MP6 & $100 \%$ & Sangat sesuai \\
MP7 & $47,37 \%$ & Cukup sesuai \\
MP8 & $100 \%$ & Sangat sesuai \\
\hline
\end{tabular}

\section{Pembahasan}

Selain melihat kesesuain isi buku dengan indikator SMP, tim peneliti juga melakukan analisis lebih lanjut berdasarkan teori dan penelitian relevan untuk melihat potensi yang dimiliki buku berdasarkan SMP dan potensi lain yang muncul.

Menggunakan alat-alat dan strategi yang tepat (MP5)

Indikator MP5 diharapkan membantu siswa mahir dalam mempertimbangkan dan menggunakan alat yang tersedia saat memecahkan masalah matematis. Alat-alat dapat berupa pensil dan kertas, penggaris, busur derajat, kalkulator, spreadsheet, sistem aljabar komputer, aplikasi statistik, atau aplikasi geometri dinamis (O'Connell \& SanGiovanni, 2013). Tingkat ketercapaian indikator MP5 yang termuat secara eksplisit dalam buku penilaian ini adalah sebesar 36,84\%. Contoh indikator MP5 pada buku penilaian dapat dilihat pada Gambar 1. 
3. Gunakanlah Geogebra (http://www.geogebra. org/cms/en/) untuk mengerjakan soal berikut.

a. Gambarlah $y=\cos 2 x$ dan $y=\cos ^{2} x$. Berdasarkan kedua grafik ini, jelaskan hubungan di antara keduanya.

b. Gambarlah $y=\cos 2 x$ dan $y=\sin ^{2} x$. Berdasarkan kedua grafik ini, jelaskan hubungan di antara keduanya.

c. Gambarlah $y=\sin 2 x$ dan $y=\sin x \cos x$. Berdasarkan kedua grafik ini, jelaskan hubungan di antara keduanya.

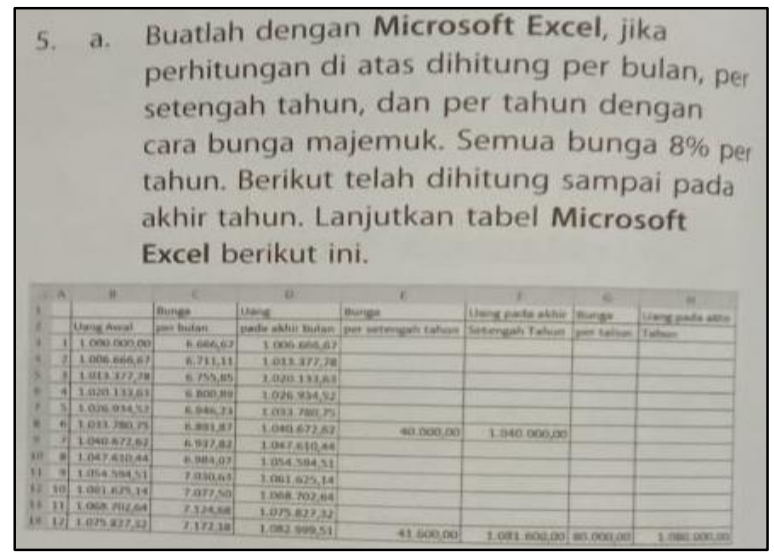
perhitungan di atas dihitung per bulan, per setengah tahun, dan per tahun dengan cara bunga majemuk. Semua bunga $8 \%$ pe ahun. Berikut telah dihitung sampai pada akhir tahun. Lanjutkan tabel Microsoft Excel berikut ini.

\section{Gambar 1. Contoh indikator MP5 pada buku}

Gambar 1 menunjukkan instruksi penggunaan aplikasi matematika yaitu geogebra serta microsoft excel untuk membantu siswa dalam menyelesaikan masalah trigonometri dan aritmetika sosial. Penggunaan aplikasi seperti geogebra dan microsoft excel tidak hanya berguna dalam menyelesaikan masalah matematis, namun juga berfungsi sebagai alat untuk mengonfirmasi suatu penyelesaian dalam permodelan matematika (Sung, 2015; Jacinto \& Carreira, 2017). Oleh sebab itu, indikator ini berhubungan erat dengan indikator MP1 dan MP4 (Araiku, Somakim, Pratiwi, Lestari, \& Faradilla, 2020). Dengan penggunaan aplikasi, siswa dapat melakukan berbagai macam percobaan matematis untuk pemahaman yang lebih baik (Kilicman, Hassan, \& Husain, 2010). Selain itu, karena tingkat ketelitian perhitungan aplikasi lebih baik dibandingkan perhitungan manual, misal dikarenakan adanya pembulatan, maka indikator ini juga terkait dengan indikator MP6.

Walaupun tingkat ketercapaian indikator ini hanya 36,84\%, namun hal ini dikarenakan aplikasi matematika yang tertulis secara eksplisit cukup minim. Pada pelaksanaannya, guru dapat mengaplikasikan aplikasi-aplikasi matematika pada materi lain, menggunakan alat-alat sederhana seperti penggaris dan kalkulator, serta website matematika seperti https://keisan.casio.com/. Oleh sebab itu, peran guru dalam merancang proses pembelajaran serta media pembelajaran yang digunakan, sehingga standar MP5 tetap dapat terpenuhi dengan baik dengan mengaplikasikan buku ini di dalam kelas.

Ketepatan (MP6)

Indikator MP6 membantu siswa dalam menyatakan makna simbol yang mereka pilih, berhati-hati dalam menentukan satuan ukuran, menghitung secara akurat dan efisien, serta mengungkapkan jawaban numerik dengan tingkat ketepatan yang sesuai untuk konteks masalah (O'Connell \& SanGiovanni, 2013).Tingkat pemenuhan indikator MP6 adalah sebesar 100\%. Pada dasarnya, seluruh masalah matematis menuntut penyelesaian yang akurat, 
terutama masalah yang berbentuk analisis dan masalah yang mengaitkan konteks dalam penyelesaiannya (CCSSI, 2020). Sebagai contoh, saat menyelesaikan masalah terkait biaya minimal untuk membeli cat, jika hasil perhitungan kebutuhan cat adalah 11,302 liter, maka biaya yang dikeluarkan haruslah biaya untuk membeli 12 liter cat, bukan 11 liter. Walaupuan secara aturan pembulatan $11,302 \approx 11$, namun karena konteksnya adalah biaya minimum berdasarkan kebutuhan cat, maka pembulatan yang dilakukan harus pembulatan ke atas (Araiku, Parta, \& Rahardjo, 2019).

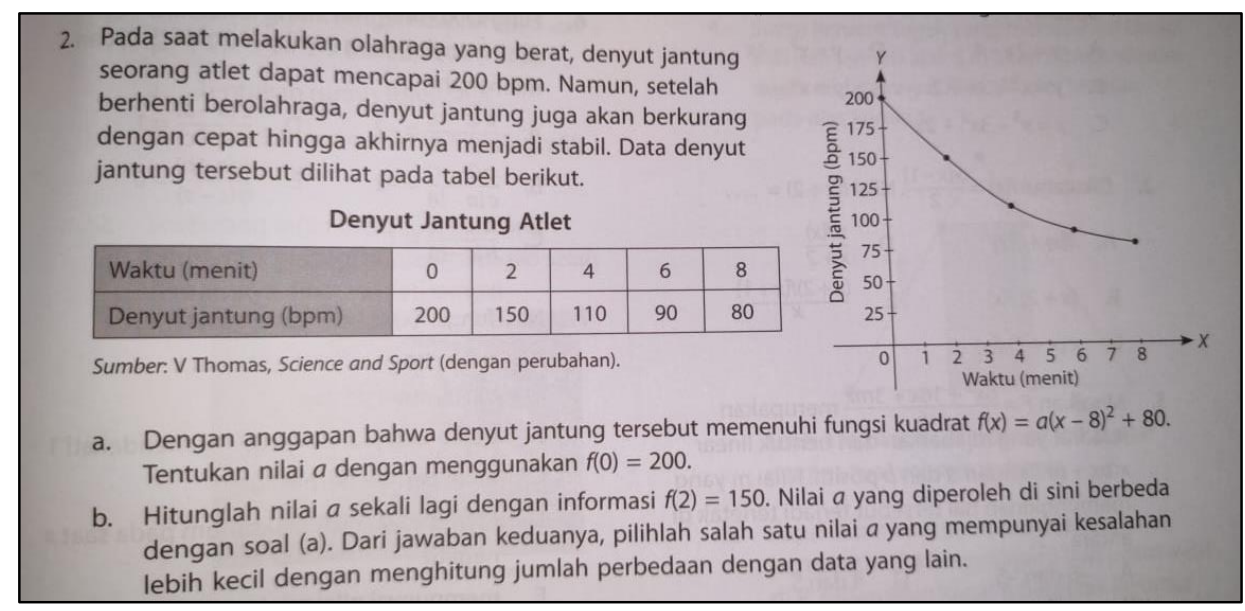

Gambar 2. Contoh indikator MP6 pada buku

Secara eksplisit, Gambar 2 merupakan contoh masalah yang menuntut ketepatan siswa hingga memiliki kesalahan terkecil. Sebagai contoh pada bagian pertanyaan (2a), diberikan sebuah fungsi kuadrat yang memodelkan detak jantung seseorang yaitu $f(x)=a(x-8)^{2}+$ 80. Kemudian siswa mencari nilai $a$ tersebut berdasarkan data yang diketahui yaitu $f(0)=$ 200, sehingga nilai $a$ adalah

$$
f(0)=a(0-8)^{2}+80=a(-8)^{2}+80=64 a+80
$$

Sehingga

$$
\begin{gathered}
64 a+80=200 \\
64 a=200-80 \\
64 a=120 \\
a=1 \frac{7}{8} .
\end{gathered}
$$

Kemudian pada bagian $(2 b)$, siswa mencari nilai $a$ berdasarkan data $f(2)=150$, sehingga diperoleh

$$
f(2)=a(2-8)^{2}+80=a(-6)^{2}+80=36 a+80
$$

Sehingga 


$$
\begin{gathered}
36 a+80=150 \\
36 a=150-80 \\
36 a=70 \\
a=1 \frac{17}{18} .
\end{gathered}
$$

Dari sini dapat dilihat bahwa nilai $a$ tidak konsisten, sehingga tidak diketahui mana nilai $a$ yang tepat atau paling mendekati kebenaran. Oleh sebab itu, diperlukan uji lanjut pada $f(4), f(6)$, dan $f(8)$ sehingga diperoleh

$$
\begin{aligned}
& f(4), \quad a=1 \frac{7}{8} \\
& f(6), \quad a=2 \frac{1}{2} \\
& f(8), \quad a=0
\end{aligned}
$$

Perhatikan bahwa setiap nilai $a$ berbeda. Sehingga untuk memilih nilai $a$ yang tepat diperlukan bimbingan guru. Salah satu caranya adalah menggunakan garis regresi untuk menentukan selisih terkecil untuk setiap nilai $a$. Hal ini dapat dilakukan secara mudah dengan menggunakan bantuan line graph pada microsoft yang dapat dilihat pada Gambar 3.

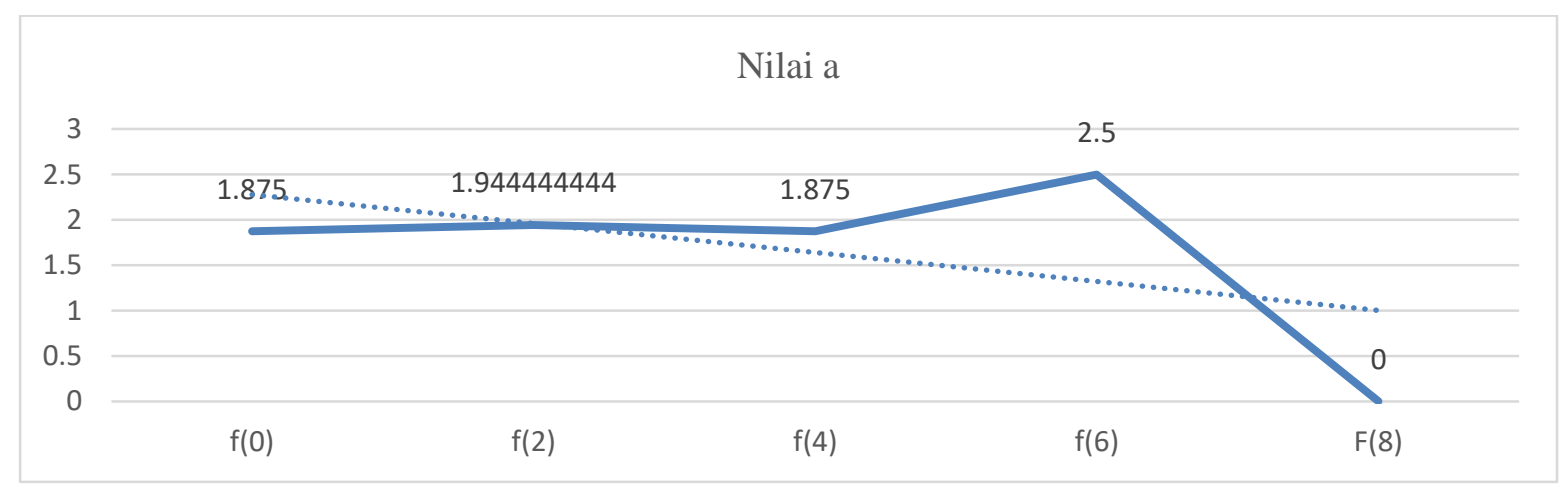

Gambar 3. Line graph pada menggunakan microsoft

Berdasarkan Gambar 3, dapat disimpulkan bahwa nilai $a$ yang paling mendekati adalah

$1 \frac{17}{18}$. Masalah tipe ini dapat membantu siswa untuk berargumentasi, berpikir kritis, serta menggunakan alat-alat yang tepat (Dede, 2019; Veleda \& Burak, 2017). Oleh sebab itu, indikator ini berkaitan erat dengan semua indikator $S M P$.

Mencari dan menggunakan pola (MP7)

Indikator MP7 menekankan pada penyelesaian masalah dengan mencari pola (CCSSI, 2020). Menentukan pola adalah salah satu strategi dalam pemecahan masalah matematika (NCTM, 2000). Persentase kemunculan MP7 pada buku ini adalah sebesar 47,37\%. Hal ini dikarenakan dalam memecahkan masalah matematika, menggunakan pola bukanlah satu- 
satunya strategi yang paling efektif dalam memecahkan masalah matematika. Masing-masing masalah dapat diselesaikan secara efisien dengan menggunakan strategi yang berbeda-beda. Salah satu contoh masalah matematis yang lebih efisien jika diselesaikan dengan menggunakan pola dapat dilihat pada Gambar 4.

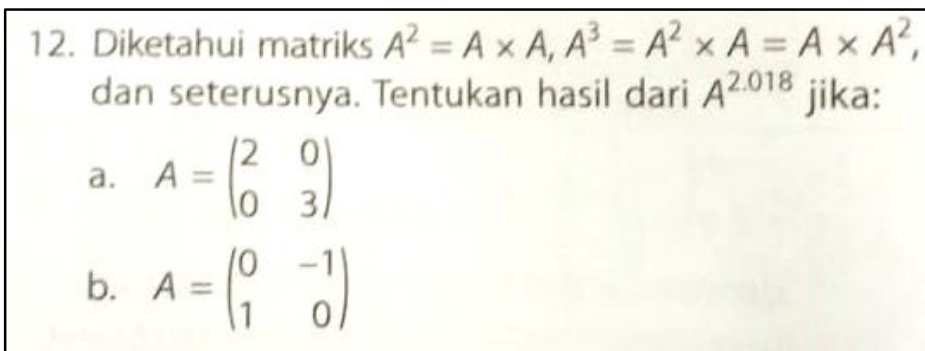

Gambar 4. Contoh indikator MP7 pada buku

Dalam menyelesaikan masalah tersebut, misalkan untuk (12a), diberikan

$$
A=\left(\begin{array}{ll}
2 & 0 \\
0 & 3
\end{array}\right)
$$

Dengan definisi $A^{2}=A \times A, A^{3}=A^{2} \times A$ dan seterusya, maka diperoleh

$$
A^{2}=\left(\begin{array}{ll}
4 & 0 \\
0 & 9
\end{array}\right) ; A^{3}=\left(\begin{array}{cc}
8 & 0 \\
0 & 27
\end{array}\right) ; A^{4}=\left(\begin{array}{cc}
16 & 0 \\
0 & 81
\end{array}\right)
$$

Untuk mencari $A^{2018}$ dengan cara perhitungan manual, maka akan memakan waktu yang sangat lama. Oleh sebab itu, dengan melihat pola, penyelesaian masalah tersebut tidak akan memakan waktu yang lama, di mana

$$
A=\left(\begin{array}{ll}
2 & 0 \\
0 & 3
\end{array}\right) ; A^{2}=\left(\begin{array}{cc}
2^{2} & 0 \\
0 & 3^{2}
\end{array}\right) ; A^{3}=\left(\begin{array}{cc}
2^{3} & 0 \\
0 & 3^{3}
\end{array}\right) ; A^{4}=\left(\begin{array}{cc}
2^{4} & 0 \\
0 & 3^{4}
\end{array}\right)
$$

Sehingga dapat diperoleh bahwa

$$
A^{2018}=\left(\begin{array}{cc}
2^{2018} & 0 \\
0 & 3^{2018}
\end{array}\right)
$$

Sedangkan untuk (12b), juga dapat dikerjakan lebih efisien dengan mendapatkan aturan tertentu, dimana

$$
A=\left(\begin{array}{cc}
0 & -1 \\
1 & 0
\end{array}\right)
$$

Dengan definisi $A^{2}=A \times A, A^{3}=A^{2} \times A$ dan seterusya, maka diperoleh

$$
A^{2}=\left(\begin{array}{cc}
-1 & 0 \\
0 & -1
\end{array}\right) ; A^{3}=\left(\begin{array}{cc}
0 & 1 \\
-1 & 0
\end{array}\right) ; A^{4}=\left(\begin{array}{cc}
1 & 0 \\
0 & 1
\end{array}\right) ; A^{5}=\left(\begin{array}{cc}
0 & -1 \\
1 & 0
\end{array}\right)
$$

Di sini dapat dilihat bahwa akan terjadi pengulangan pola setelah $A^{4}$, dimana $A^{5}=A, A^{6}=$ $A^{2}, A^{7}=A^{3}, A^{8}=A^{4}, A^{9}=A^{5}=A$, dan seterusnya. Oleh sebab itu, untuk mencari $A^{2018}$ tidak diperlukan perkalian manual sebanyak 2018 kali, cukup dengan melihat pola yang diperoleh, dimana $2018=2016+2=4(504)+2$, sehingga diperoleh 


$$
A^{2018}=A^{2}=\left(\begin{array}{cc}
-1 & 0 \\
0 & -1
\end{array}\right)
$$

Penggunaan strategi menemukan pola dalam menyelesaikan masalah dapat membantu siswa untuk meningkatkan kemampuan membuat generalisasi dan berpikir kreatif, terutama kefasihan dan fleksibilitas (Vale, Pimentel, Cabrita, Barbosa, \& Fonseca, 2012). Selain itu, pola dan struktur dalam matematika membantu siswa dalam memahami kuantitas dan konsep (O'Connell \& SanGiovanni, 2013).

Mencari dan menyatakan keteraturan dalam penalaran berulang

Indikator MP8 menekankan pada menemukan dan menggunakan pola sebagai strategi pemecahan masalah yang efektif (O'Connell \& SanGiovanni, 2013). Implikasi dari MP8 adalah proses ketika siswa melihat dan memanfaatkan hubungan antara masalah dan perhitungannya (Illustrative-Mathematics, 2014; Clayton, 2014). Penalaran berulang memungkinkan siswa untuk mengambil jalan pintas dengan menemukan suatu aturan berdasarkan pemahaman dan pengalamannya. Masalah-masalah matematis yang mungkin untuk mendorong munculnya indikator ini adalah yang menekankan pada solusi yang efisien dengan membandingkan beberapa metode penyelesaian atau dengan menggunakan penalaran berjenjang untuk menentukan suatu aturan baru. Persentase kesesuaian MP8 pada buku matematika yang dianalisis adalah sebesar $100 \%$. Contoh masalah yang menekankan pada proses ini ditunjukan pada Gambar 5.

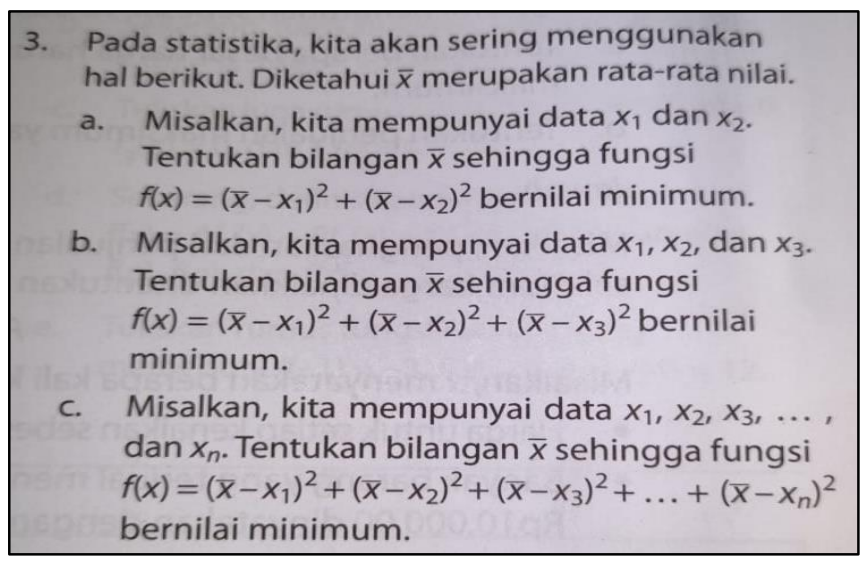

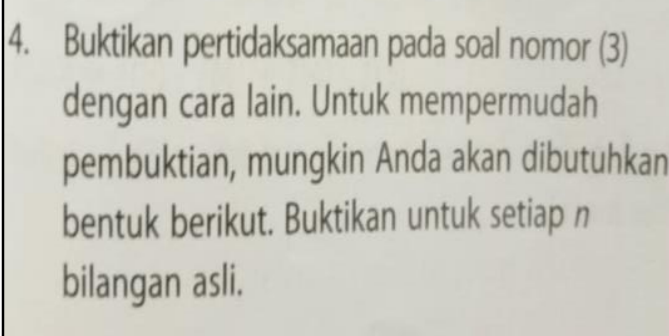

Gambar 5. Contoh indikator MP8 pada buku

Misalkan salah satu penyelesaian nomor $a$ pada Gambar 5 (kiri) adalah sebagai berikut. Diberikan suatu fungsi

$$
f(x)=\left(\bar{x}-x_{1}\right)^{2}+\left(\bar{x}-x_{2}\right)^{2}
$$

Karena $\left(\bar{x}-x_{1}\right)^{2}$ dan $\left(\bar{x}-x_{2}\right)^{2}$ akan selalu lebih dari atau sama dengan 0 , maka nilai $f(x)$ terkecil yang mungkin adalah 0 . Nilai ini hanya akan tercapai bila $\left(\bar{x}-x_{1}\right)^{2}=0$ dan 
$\left(\bar{x}-x_{2}\right)^{2}=0$. Sehingga $\bar{x}=x_{1}$ dan $\bar{x}=x_{2}$. Akibatnya $\bar{x}=x_{1}=x_{2}$. Oleh sebab itu, $f(x)$ akan bernilai 0 jika $\bar{x}=x_{1}=x_{2}$. Dengan cara serupa, untuk masalah $b$ dan $c$ akan diperoleh solusi $\bar{x}=x_{1}=x_{2}=x_{3}$ dan $\bar{x}=x_{1}=x_{2}=x_{3}=\cdots=x_{n}$ agar $f(x)$ bernilai minimum.

Solusi yang diberikan di atas tidak tunggal. Siswa dapat menyelesaikan masalah tersebut dengan menggunakan pendekatan berbeda, misalnya untuk nomor $a$ dengan menggunakan definisi rata-rata

$$
\bar{x}=\frac{x_{1}+x_{2}}{2}
$$

Sehingga solusi yang diberikan sebagai berikut

$$
\begin{gathered}
f(x)=\left(\bar{x}-x_{1}\right)^{2}+\left(\bar{x}-x_{2}\right)^{2} \\
f(x)=\left(\frac{x_{1}+x_{2}}{2}-x_{1}\right)^{2}+\left(\frac{x_{1}+x_{2}}{2}-x_{2}\right)^{2} \\
f(x)=\left(\frac{x_{1}+x_{2}}{2}-\frac{2 x_{1}}{2}\right)^{2}+\left(\frac{x_{1}+x_{2}}{2}-\frac{2 x_{2}}{2}\right)^{2} \\
f(x)=\left(\frac{x_{2}-x_{1}}{2}\right)^{2}+\left(\frac{x_{1}-x_{2}}{2}\right)^{2} \\
f(x)=\left(\frac{x_{1}-x_{2}}{2}\right)^{2}+\left(\frac{x_{1}-x_{2}}{2}\right)^{2} \\
f(x)=2\left(\frac{x_{1}-x_{2}}{2}\right)^{2} \\
f(x)=\frac{1}{2}\left(x_{1}-x_{2}\right)^{2} .
\end{gathered}
$$

Nilai minimum akan diperoleh jika $x_{1}=x_{2}$. Sehingga

$$
\bar{x}=\frac{x_{1}+x_{2}}{2}=\frac{x_{1}+x_{1}}{2}=\frac{2 x_{1}}{2}=x_{1} .
$$

Akibatnya $\bar{x}=x_{1}=x_{2}$.

Contoh lain, masalah pada Gambar 5 (kanan) mengharuskan siswa untuk membuktikan suatu pertidaksamaan dengan metode selain dengan yang telah diberikan sebelumnya. Karena masalah tersebut dapat diselesaikan dengan lebih dari satu metode, maka masalah tersebut dapat digolongkan ke dalam masalah terbuka (open-ended problem). Penggunaan masalah terbuka dalam proses pembelajaran matematika memiliki beberapa keuntungan terutama untuk meningkatkan kemampuan berpikir kreatif (Damayanti \& Sumardi, 2018; Fatah, Suryadi, Sabandar, \& Turmudi, 2016). Adanya perbandingan beberapa metode memungkinkan siswa untuk mengembangkan kemampuan argumentasinya, terutama dalam hal menemukan solusi dengan menggunakan strategi yang paling efisien (Dwyer, Hogan, \& Stewart, 2011; Firdaus, 2015). Lebih lanjut, ketika siswa mengembangkan dan memperbaiki strategi untuk perhitungan 
yang lebih efisien, maka ketepatan dengan perhitungan meningkat (CCSSI, 2020; O'Connell \& SanGiovanni, 2013). Oleh sebab itu, indikator ini berkaitan erat dengan MP1, MP4, MP5 dan MP6.

Kelebihan Buku Matematika yang Dianalisis Selain Kesesuaian dengan Indikator SMP

Salah satu media yang dapat digunakan agar siswa dapat lebih memahami materi matematika yang telah diajarkan dan membuat proses pembelajaran menjadi lebih menyenangkan adalah video tutorial (Allen \& Smith, 2012; Hsin \& Cigas, 2013; Zahn, 2010). Berdasarkan hasil penelitian, video tutorial membantu siswa mengingat dan memahami dengan lebih baik. Tingkat pemahaman materi siswa secara klasikal dengan proses pembelajaran berbantuan video tutorial meningkat dari $40 \%$ menjadi 75\% (Lindstorm, 1994).

Selain pemenuhan $S M P$, buku ini juga dilengkapi dengan video tutorial yang dapat diakses dengan memindai barcode yang terdapat di setiap bab. Video tutorial ini berisi penjelasan mengenai konsep matematis dan beberapa teknik dalam menyelesaikan masalah matematis yang terdapat di dalam buku. Gambar 6 dan Gambar 7 merupakan contoh tampilan barcode dan video tutorial yang terdapat dalam buku.

Fasilitas video tutorial ini tidak hanya terdapat pada bagian eksplorasi konsep, namun juga dalam masalah matematis dengan berbagai tingkat kesulitan yang berbeda. Hal ini tentunya akan sangat membantu siswa untuk dapat belajar secara mandiri kapan pun dan di mana pun. Dengan adanya fitur ini, maka buku penilaian matematika ini tepat digunakan untuk pembelajaran yang berbasis blended learning. Lebih lanjut, buku ini menjadi sangat baik untuk digunakan terutama pada masa pandemi COVID-19 di mana siswa diharuskan untuk belajar di rumah.

\section{Eksplorasi}

Tuliskan bentuk $|2 x|$ dan $|2||x|$ tanpa menggunakan nilai mutlak.

a. Untuk $x \geq 0$.

b. Untuk $x<0$.

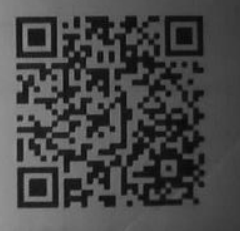

c. Tuliskandugaan hubunganantara $|2 x|$ dan $|2||x|$.

Gambar 6. Contoh tampilan barcode pada buku 


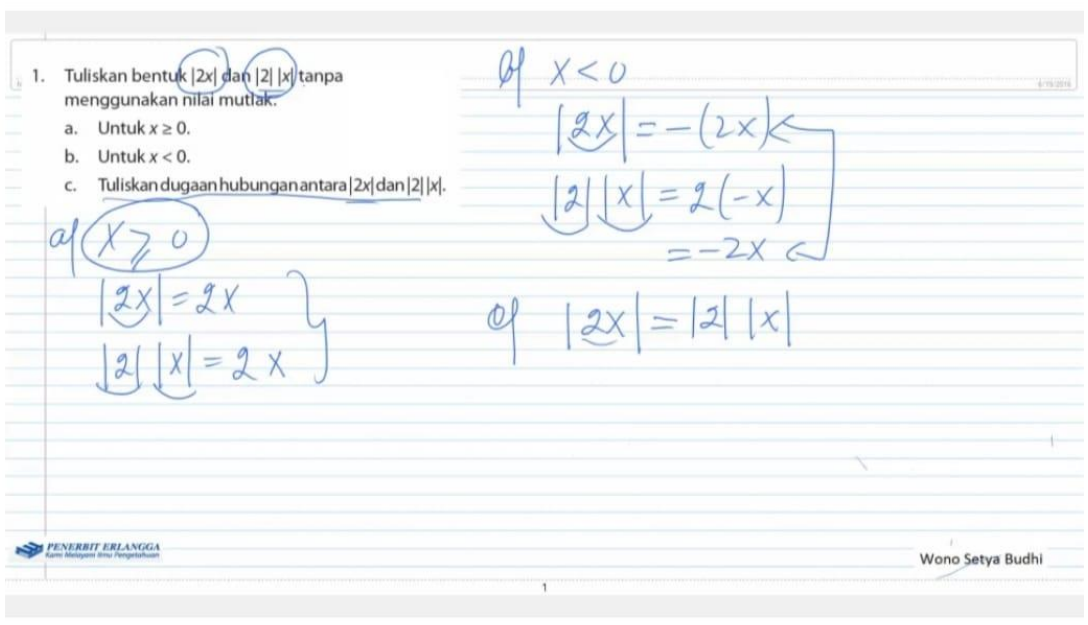

Gambar 7. Contoh video tutorial

\section{SIMPULAN DAN SARAN}

\section{Simpulan}

Hasil analisis terhadap isi buku menunjukkan bahwa buku penilaian matematika wajib SMA karya Prof. Wono Setya Budhi, Ph.D. telah sesuai dengan Standard for Mathematical Practice (SMP), di mana persentase kesesuaian MP5 sebesar 36,84\%, MP6 dan MP8 sebesar $100 \%$, serta MP7 sebesar 47,37\%. Dengan adanya kesesuaian buku dengan indikator SMP, maka dengan menggunakan buku ini dapat membantu untuk mengembangkan kemampuan berpikir dan motivasi siswa dalam belajar.

Lebih lanjut, buku ini memiliki kelebihan dibandingkan dengan buku lain, di mana selain memiliki masalah dengan tingkat kesulitan dan konteks yang beragam, buku ini juga dilengkapi bengan barcode yang mengarahkan pada video tutorial, di mana video tutorial yang diberikan terdapat di setiap bab dan membahas berbagai bagian buku mulai dari eksplorasi konsep hingga menyelesaikan masalah matematis.

\section{Saran}

Dengan persentase MP5 dan MP8 yang cukup kecil (kurang dari 50\%), hal ini dapat diatasi dengan peran guru dalam merancang proses pembelajaran dan media yang digunakan, serta strategi pemecahan masalah yang sesuai dengan masalah matematis yang diberikan. Selain itu, dengan adanya fitur video tutorial, sangat disarankan untuk menggunakan buku ini terutama pada masa pandemi COVID-19, sehingga siswa dapat belajar secara mandiri di rumah. 


\section{UCAPAN TERIMA KASIH}

Penulis mengucapkan terima kasih yang sebesar-besarnya kepada Universitas Sriwijaya yang telah mendanai penelitian ini. Penelitian ini didanai oleh hibah Fakultas Keguruan dan Ilmu Pendidikan Universitas Sriwijaya melalui skema Sains, Teknologi, dan Seni (SATEKS) 2020.

\section{DAFTAR PUSTAKA}

Allen, W., \& Smith, A. (2012). Effects of video podcasting on psychomotor and cognitive performance, attitudes and study behavior of student physical therapists. Innovations in Education and Teaching International, 49, 401-414.

Apino, E., \& Retnawati, H. (2016). Developing mathematical higher order thinking skills of senior high school students. MSCEIS (pp. 1-8). Bandung: Universitas Pendidikan Indonesia.

Araiku, J., Parta, I. N., \& Rahardjo, S. (2019). Analysis of students' mathematical problem solving ability as the effect of constant ill-structured problem's employment. Journal of Physics: Conference Series, 1166(1), 12-20. doi:10.1088/1742-6596/1166/1/012020

Araiku, J., Somakim, Pratiwi, W. D., Lestari, A. O., \& Faradilla, N. (2020). Analisis buku penilaian (bupena) matematika wajib berdasarkan standards for mathematical practice (smp). Lentera Sriwijaya : Jurnal Ilmiah Pendidikan Matematika, 2(1), 55-66. doi:10.36706/jls.v2i1.11540

Arroida, A. K., \& Retnawati, E. (2018). Analisis buku teks pelajaran matematika wajib kelas x sma. Jurnal Pendidikan Matematika, 7(3), 1-13.

Basturkmen, H. (2010). Developing courses in english for specific purposes. New York: Paglave Macmillan.

Borg, W., Gall, M., \& Gall, J. (2003). Educational research: An introduction. New York: Longman.

CCSSI. (2020, April 2). Standards for mathematical practice. Retrieved from Common Core State Standards Initiative: http://www.corestandards.org/Math/Practice/

Čeretková, S., Šedivý, O., Molnár, J., \& Petr, D. (2008). The role and assessment of textbooks in mathematics education. Problems of Education in The 21st Century, 6, 27-37.

Chang, C. C., \& Silalahi, S. M. (2017). A review and content analysis of mathematics textbooks in educational research. Problems of Education in 21st Century, 75(3), 235-251.

Clayton, H. (2014). The thinking behind the content: Standards for mathematical practice. Making the Common Core Come Alive!, 3(2), 1-10. Retrieved from Just Ask: Publications and Profesional Development. 
Courtney, S. A. (2014). Moving the standards for mathematical practice beyond bullet points. Comprehensive Journal of Educational Research, 2(5), 70-87.

Damayanti, H. T., \& Sumardi. (2018). Mathematical creative thinking ability of junior high school students in solving open-ended problem. Journal of Research and Advances in Mathematics Education, 3(1), 36-45.

Dede, A. T. (2019). Arguments constructed within the mathematical modelling cycle. International Journal of Mathematical Education in Science and Technology, 50(2), 292314. doi:10.1080/0020739X.2018.1501825

Dwyer, C., Hogan, M., \& Stewart, I. (2011). The promotion of critical thinking skills through argument mapping. In C. P. Forte, Critical Thinking (pp. 1-25). New York: Nova Science Publishers, Inc.

Eyyam, R., \& Yaratan, H. S. (2014). Impact of use of technology in mathematics lessons on student achievement and attitudes. Journal of social behavior and personality, 42, 3142. doi:10.2224/sbp.2014.42.0.S31

Farzan, M. (2009). Riazie sale sevom rahnamyii. Tehran: Sherkate Chap va Nashre Ketabhaye Darsi.

Fatah, A., Suryadi, D., Sabandar, J., \& Turmudi. (2016). Open-ended approach: an effort in cultivating students' mathematical creative thinking ability and self-esteem in mathematics. Journal on Mathematics Education, 7(1), 9-18.

Firdaus, I. K. (2015). Developing critical thinking skills of students in mathematics learning. Journal of Education and Learning, 9(3), 226-236.

Gene, K., Zacharos, K., Lavidas, K., \& Koustourakis, G. (2018). An analysis of school mathematics textbooks in terms of their pedagogical orientation. Open Journal for Educational Research, 2(1), 1-18.

Graves, K. (2000). Designing Language Course, A Guide for Teachers. Boston: Cengage Learning.

Hsin, W., \& Cigas, J. (2013). Short videos improve student learning in online education. Journal of Computing Sciences in Colleges, 28, 253-259.

Illustrative-Mathematics. (2014, February 12). Standards for mathematical practice: commentary and elaborations for $k-5$. Retrieved from Common Core Tools: http://commoncoretools.me/wp-content/uploads/2014/02/Elaborations.pdf 
Jacinto, H., \& Carreira, S. (2017). Mathematical problem solving with technology: the technomathematical fluency of a student-with-geogebra. International Journal of Science and Mathematics Education, 15(6), 1115-1136. doi:10.1007/s10763-016-9728-8

Kilicman, A., Hassan, M. A., \& Husain, S. S. (2010). Teaching and learning using mathematics software "the new challenge". Procedia Social and Behavioral Sciences, 8, 613-319. doi:10.1016/j.sbspro.2010.12.085

Li, Y. (2000). A comparison of problems that follow selected content presentations in American and Chinese mathematics. Journal for Research in Mathematics Education, $31(2), 234-241$.

Lindstorm, R. (1994). The business week guide to multimedia presentations: create dynamic presentations that inspire. New York: McGraw-Hill.

Magfirah, Maidiyah, E., \& Suryawati. (2019). Analisis kesalahan siswa dalam menyelesaikan soal cerita matematika berdasarkan prosedur newman. Lentera Sriwijaya: Jurnal Ilmiah Pendidikan Matematika, 1(2), 1-12. doi:10.36706/jls.v1i2.9707

Mateas, V. (2016). Debunking myths about the standards for mathematical practice. Mathematics Teaching In The Middle School, 22(2), 92-99.

Mayer, R. E., Sims, V., \& Hidet, T. (1995). A comparison of how textbooks teach mathematical problem solving in Japan and the United States. American Educational Research Journal, 32(2), 443-460.

NCTM. (2000). Principles and standards for school mathematics. Reston, Virginia: NCTM.

O'Connell, S., \& SanGiovanni, J. (2013). Putting the practices into action: implementing the common core standards for mathematical practice. Canada: Pearson Canada Inc.

Okeeffe, L. (2013). A framework for textbook analysis. International Review of Contemporary Learning Research, 2(1), 1-13.

Robitaille, D., \& Travers, K. (1992). International studies of achievement in mathematics. In D. Grouws, Handbook of Research on Mathematics Education (pp. 687-709). New York: Macmillan Publishing Company.

Schmidt, W. H., McKnight, C., Valverde, G., Houang, R., \& Wiley, D. (1997). Many visions, many aims - volume 1 (A cross national investigation of curricular intentions in school mathematics). London: Kluwer Academic Publisher.

Sung, C. T. (2015). Building mathematical models in excel: A guide for agriculturists. Boca Raton: Universal Publisher.

Tajudin, N. M. (2017). Role of higher order thinking skills in enhancing mathematical problem solving. Man in India, 97(17), 209-214. 
Taqiyuddin, M. (2019, November 11). https://www.researchgate.net/. Retrieved from researchgate:

https://www.researchgate.net/publication/333015100_ANALISIS_BUKU_MATEMAT IKA_SEKOLAH_MENENGAH_ATAS_PADA_TOPIK_TURUNAN/link/5cd662ce2 99bf14d9589c384/download

Vale, I., \& Cabrita, I. (2008). Learning through patterns: a powerful approach to algebraic thinking. The Proceedings of the 18th Annual Conference of the European Teacher Education Network (pp. 62-69). Helsinki: University of Helsinki.

Vale, I., Pimentel, T., Cabrita, I., Barbosa, A., \& Fonseca, L. (2012). Pattern problem solving tasks as a mean to foster creativity in mathematics. The 36th Conference of the International Group for the Psychology of Mathematics Education. 4, pp. 171-178. Taipei: PME.

Valverde, G., Bianchi, L., Wolfe, R., Schmidt, W., \& Houang, R. (2002). According to the book: Using timss to investigate the translation of policy into practice through the world of textbooks. London: Kluwer Academic Publisher.

Van den Heuvel-Panhuizen, M., \& Wijers, M. (2005). Mathematics standards and curricula in the Netherlands. Zentralblatt für Didaktik der Mathematik, 37, 287-307. doi:10.1007/BF02655816

Veleda, G. G., \& Burak, D. (2017). Mathematical modelling in mathematics education as a way to develop critical consciousness: A theoretical essay. Acta Scientiae, 19(2), 211223.

Widjaja, W. (2013). The use of contextual problems to support mathematical learning. IndoMS$J M E, 4(2), 151-159$.

Zahn, C. P. (2010). Comparing simple and advanced video tools as supports for complex collaborative design processes. The journal of the learning sciences, 19, 403-440. 